\title{
Activation-associated death of memory $b$ cells in peripheral circulation in adults with sepsis
}

\author{
M Shankar-Hari ${ }^{1,2^{*}}$, R Beale ${ }^{2}$, M Singer $^{3,4}$, J Spencer ${ }^{1}$ \\ From ESICM LIVES 2015 \\ Berlin, Germany. 3-7 October 2015
}

\section{Introduction}

In sepsis, impaired function and loss of antigen-presenting cells are observed in secondary lymphoid organs [1], the site where antigen-dependent $B$ cell differentiation occurs in health. How these changes in sepsis affect $B$ cell differentiation into memory $\mathrm{B}$ cells is at present undefined.

\section{Objectives}

To study seven-day lymphocyte and immunoglobulin trajectory, alterations in B cell subsets and potential mechanisms in septic ICU patients.

\section{Methods}

Adults with severe sepsis from community-acquired infections without documented immunosuppression were enrolled. Hypogammaglobulinaemia and absolute lymphopenia were defined as $\operatorname{IgG}<6.1, \operatorname{IgM}<0.4$, $\operatorname{IgA}<$ $0.8 \mathrm{~g} / \mathrm{L}$ and lymphocytes $<1.2 \times 10^{9} / \mathrm{L}$, respectively.

Flow cytometry [FACScalibur [BD Biosciences]; FlowJo software,] was used for:

- Identifying naïve, transitional, IgM, IgG and IgA memory and plasmablasts using anti-human CD19PerCpCy5.5, IgG-APC H7, IgM-V450, CD24-PeCy7 [all BD Biosciences], IgA-FITC, CD38-PE, Annexin V Apoptosis detection set PE-Cy7 [all eBioscience] and livedead stain [Invitrogen]. ADDIN EN.CITE ADDIN EN. CITE.DATA [2], [3]

- Intracellular staining to assess phosphorylated kinase expression in B cells [p-ERK-PE, p-BTK-alexafluor 647, p-SYK-alexafluor 488, p-AKT-APC [all BD Biosciences].

- FMO and isotype controls were used to define population gates.

King's College London, Department of Immunobiology, London, United Kingdom

Full list of author information is available at the end of the article
B cell survival ligands [BAFF, APRIL] were measured using ELISA.

Differentially expressed genes in sepsis are reported [RT-q-PCR, TaqMan ${ }^{\circledR}$ Human Apoptosis Array; false discovery rate $=5 \%]$.

Statistics were performed using paired and unpaired $t$ test or non-parametric equivalent with adjustment for collinear measurements.

\section{Results}

101 patients were studied. On their first ICU day, 46\% had hypogammaglobulinaemia and $76 \%$ absolute lymphopenia with absolute low B [75\%] and T [100\%] lymphocyte counts. Trajectory of significantly higher increment immunoglobulins and lymphocyte counts occur earlier in survivors compared to non-survivors.

In sepsis [compared to healthy controls, $\mathrm{n}=$ variable] there was

- Preferential apoptotic loss of memory B cells and plasmablasts, with apoptotic cells showing higher phosphorylated extracellular signal-regulated kinases [p-ERK fluorescence], but no differences in the phosphorylated $B$ cell receptor linked kinases [p-BTK, p-SYK] and protein kinase $\mathrm{B}$.

- BAFF/APRIL levels were normal.

- Fas and bcl-2 apoptosis regulator genes were up regulated.

\section{Conclusions}

In sepsis, activation-associated B cell apoptosis and changes in secondary lymphoid organs deplete B cell memory and contribute to long-term immunosuppression in survivors.

\section{Grant Acknowledgment}

UK NIHR, Biomedical Research Centre at Guy's and St Thomas' NHS Trust \& King's College London. 


\section{Authors' details}

'King's College London, Department of Immunobiology, London, United Kingdom. ${ }^{2}$ Guy's and St Thomas' NHS Foundation Trust, Critical Care Medicine, London, United Kingdom. ${ }^{3}$ University College London, Intensive Care Medicine, London, United Kingdom. ${ }^{4}$ University College London, Research Department of Clinical Physiology, Division of Medicine, London, United Kingdom.

Published: 1 October 2015

\section{References}

1. Hotchkiss RS, et al: Nat Rev Immunol 2013, 13:862-874.

2. Maecker H, et al: Nat Rev Immunol 2012, 12:191-200.

3. Berkowska MA, et al: Blood 2011, 118:2150-2158.

doi:10.1186/2197-425X-3-S1-A621

Cite this article as: Shankar-Hari et al: Activation-associated death of memory b cells in peripheral circulation in adults with sepsis. Intensive Care Medicine Experimental 2015 3(Suppl 1):A621.

\section{Submit your manuscript to a SpringerOpen ${ }^{\mathcal{O}}$ journal and benefit from:}

- Convenient online submission

- Rigorous peer review

- Immediate publication on acceptance

- Open access: articles freely available online

- High visibility within the field

- Retaining the copyright to your article

Submit your next manuscript at $\gg$ springeropen.com 